\title{
Pandemie v Jižní Americe: politické a sociální konsekvence
}

\author{
Alessandro Pinzani \\ Universidade Federal de Santa Catarina, BRA \\ Filosofický ústav Akademie věd ČR, $\mathrm{CZ}$
}

\begin{abstract}
PINZANI, A.: The Pandemic in South America: Political and Social Consequences

Philosophica Critica, vol. 6, 2020, no. 1, ISSN 1339-8970, pp. 127-139
\end{abstract}

In the present COVID-19 pandemic, South American countries are facing difficult challenges that go beyond the medical aspects. In this paper, in which I focus mostly on Brazil as a paradigmatic case, I defend that the pandemic is exposing the fragility of the state (not just of its institutions, but of its very idea) in this macro-region and in Brazil in particular, and may therefore have a negative impact not only on the health of the citizens and on the national economies, but also on the social fabric at large. The paper discusses, first, the situation in South America at large and, second, the politicization of the crisis provoked by the Brazilian president Bolsonaro and his followers. After presenting the economic measures taken by the Brazilian government and the popular reaction, I will offer comments on the weakness of the state and on the lack of national and international solidarity in Brazil and in South America.

Key words: COVID-19 - South America - State - Civic solidarity

V současné pandemii COVID-19 čelí jihoamerické země náročným výzvám, které překračují lékařské aspekty. Pandemie pochopitelně vyvolává sociální a politické problémy také v jiných makroregionech světa, ale na rozdíl například od Evropské unie mají státy Jižní Ameriky nejisté veřejné systémy zdravotní péče, sociálního zabezpečení a civilní obrany. To poukazuje na skutečnost, že není snadné posoudit, jak virus postihuje tyto země z epidemiologického hlediska, protože chybí spolehlivé statistiky týkající se skutečného počtu postižených osob a úmrtí vyvolaných virem.

Pandemie se sice ve většině zemí Jižní Ameriky zatím ještě příliš nerozšírila, ale už se zpolarizovaly politické a organizační př́ístupy k jejímu řešení. Brazílie a Argentina, jež jsou dvěmi hlavními ekonomikami 
makroregionu, jsou kontrastními př́klady. Pravděpodobně nejvíce šokující záběry z Jižní Ameriky pocházejí z Ekvádoru, kde jsou mrtvoly ponechávány na ulicích, jelikož jsou úřady i pohřební služby zcela zahlceny. Takové fotografie připomínají středověké popisy morové epidemie. Člověk by je v Ekvádoru neočekával, přestože může být tato země považována za rozvojovou zemi. Mezinárodní měnový fond hodnotí Ekvádor na 59. místě ze 186 zemí podle nominálního HDP (čímž předchází o jedno místo Slovensko) (World Economic Outlook Database, 2019).

Místní a ústřední orgány zemí Jižní Ameriky nejsou schopny omezit epidemii, testovat obyvatelstvo, pečovat o postižené jedince a realizovat další náležitosti. I když těmto problémům čelí i evropské země, v Jižní Americe se stávají viditelně nepřekonatelnými. Důvodem je především relativně nerozvinutý státní aparát. Ve většině jihoamerických zemí je pouze kolem $10 \%$ (8 \% v Chile, $12 \%$ v Brazílii) z oficiálně registrovaných pracovníků státními zaměstnanci oproti průměru OECD 21 \% (nepočítáme-li velký počet neoficiálních pracovníků, kteří by vlastně převyšovali procento státních zaměstnanců). Podíváme-li se na absolutní čísla, věc je ještě jasnější: v roce 2012 bylo v Brazílii přibližně 3 miliony veřejných zaměstnanců, $\mathrm{tj} .1,6 \%$ populace, a $\mathrm{v}$ posledních letech mohl počet dokonce klesnout, což se projevilo vícero škrty ve veřejných výdajích. Zejména $v$ Brazílii to jde ruku v ruce společně s hlubokou nedůvěrou k veřejné službě (Fernandes 1981; Power - Jamison 2005; Avritzer 2019). Ve veřejném diskurzu je docela běžné vidět, jak jsou státní zaměstnanci shazováni jako „paraziti“ (současný brazilský ministr hospodářství Paulo Guedes výslovně užil tohoto výrazu, MercoPress, 2020). Slabost veřejného správy má v některých případech historické kořeny (například v Brazílii), případně je výsledkem změn v poslední době často $v$ důsledku finanční krize (jako v Argentině) nebo uskutečnění neoliberálních reforem (v př́ípadě Chile během Pinochetova režimu a v ostatních zemích kvưli podmínkám prosazeným Mezinárodním měnovým fondem nebo Světovou bankou). Na rozdíl od Evropy, kde hrály státy vždy hlavní roli v budování zdravotní péče, jihoamerické státy raději spoléhaly na soukromé iniciativy, případně vybudovaly velké, avšak nedostatečně finančně podporované zdravotnické systémy, které nejsou a nebudou schopny čelit pandemii, což si teprve nyní vlády začínají uvědomovat.

Přesto jsou v Jižní Americe rozdíly ve způsobu, jakým zasahuje pandemie různé země ze sociálního, ekonomického a politického hlediska. Téměř všechny země se podrobily nějaké formě karantény, avšak pouze v Brazílii se nejvyšší politická autorita (federální prezident Bolsonaro) proti takovýmto opatřením místních autorit vyhranila. Na rozdíl od Brazílie postupovala Argentina na národní úrovni velmi rychle, přičemž federální vláda 
spolu s prezidentem Fernándezem vyzvala k úplné karanténě. Výsledkem je, že počet infikovaných lidí a úmrtí je výrazně nižší než v Brazílii, vezmeme-li v potaz příslušné dimenze zemí. Země nebyla rozdělena politickými boji tak jako v Brazílii, a dokonce i opoziční média podporují karanténu a nouzová ekonomická opatření přijatá vládou, aby pomohla chudým a zranitelným.

Brazílie byla 5. 5. 2020 zemí s nejvyšším počtem případů (více než 114000 ) a nejvíce úmrtími (více než 7000 ), avšak ve vztahu k počtu obyvatel byl Ekvádor koncem dubna zemí s nejvíce př́pady (1 375 na milion) a nejvíce úmrtími (49 na milion), spolu s Peru druhou nejzasaženější zemí (946 př́padů na milion, 26 úmrtí na milion) a Brazílií na třetím místě úmrtími (24 na milion), ale na pátém místě př́ípady (345 na milion) za Chile (751 na milion) a Francouzskou Guyanou (419 na milion). Je však obtížné říci, kolik př́ípadů a úmrtí souvisejících s COVID-19 v makroregionu je. Např́ílad v Brazílii od 17. března (první oficiální smrt COVID-19) došlo k nárůstu o $1035 \%$ úmrtí vyvolaných závažným akutním respiračním syndromem ve srovnání se stejným obdobím v roce 2019 (Cartórios registram aumento de 1.035 \% nas mortes por síndrome respiratória 2020), i když oficiální počet úmrtí na COVID-19 je mnohem nižší. Ještě větší je nárůst počtu úmrtí „Z neurčených příčin“ (v Rio de Janeiro o 8666 \% více než v roce 2019) (Notificações de mortes por causa indeterminada disparam em cartórios do Rio 2020). Důvodem je skutečnost, že ve většině př́ípadů úmrtí, ke kterým dochází mimo nemocnice, se neprovádějí žádné testy post mortem, takže COVID-19 není označen jako příčina smrti. Pravděpodobně bude nějakou dobu trvat, než bude možné získat realistickou představu o úmrtích v regionu porovnáním absolutního počtu úmrtí během krize v roce 2020 s stejným obdobím za posledních pět let.

\section{COVID-19 v Brazílii: Bolsonarovo zpolitičtění krize}

Nyní se zaměřím na Brazílii jako př́klad toho, jak pandemie ovlivňuje nejen veřejné zdraví a národní hospodářství, ale také sociální strukturu jihoamerických zemí. Nákaza se podle oficiálních zdrojů začala rozšiřovat v Brazílii 26. 2. potvrzením prvních pozitivně testovaných pacientů v São Paulu. K 5. 5. 2020 je počet potvrzených případů 114 715, počet úmrtí 7 921. První úmrtí bylo hlášeno 17. března. V následujících dnech místní vlády několika států (Brazílie je federativní republikou) vyhlásily určitou formu uzavření zejména $\mathrm{v}$ případě škol; veřejné univerzity pozastavily přednášky, obchody byly zavřeny, továrny zastavily nebo snížily produkci (Os governos municipais frente ao Coronavírus 2020). Jako v mnoha evropských zemích, i zde se tato restriktivní opatření postupně zvyšovala, 
čímž přerušila veřejný život. Přesto však není vždy snadné taková opatření zavést. Některé státy nedávno uvolnily karanténní opatření částečně kvůli tlaku ekonomických zájmů firem a podnikatelů, částečně kvůli ztrátám z daňových př́ijmů, které ohrožují řádné fungování států při absenci dostatečné podpory federální vlády. Uvidí se, zda tento krok vyvolá nárůst př́ípadů, jak předpovídají zdravotní instituce.

Brazilský prezident Bolsonaro, který na počátku sírení viru nazval COVID-19 rýmičkou a přirovnal ji k horší chřipce, nejprve nechtěl připustit, že se jedná o krizi. Neustále si stěžuje, že média zbytečně vyvolávají hysterický humbuk a fantazírují (Bolsonaro diz que "pequena crise" do coronavírus é "mais fantasia" e não "isso tudo" que mídia propaga 2020). Důrazně kritizoval opatření místních orgánů a opakovaně prohlašoval, že „lék je horší než nemoc, kterou má léčit“. Jelikož je ekonomika silně poškozena karanténou, dle Bolsonara budou lidé trpět více kvůli ní než kvůli viru. Bolsonaro otevřeně vzdoroval varováním zdravotních úřadů včetně varování jeho ministra zdravotnictví Luize Henriqueho Mandetty, jehož nejprve zastrašoval a poté zbavil funkce. Nový ministr zdravotnictví Nelson Teich musí být nevýrazný, vyhýbat se střetům s Bolsonarem a zůstat velmi tichý ohledně opatření, která mají být přijata proti šíření viru. Bolsonaro odmítl zveřejnění svého koronavirového testu veřejnosti, přestože Kongres a soud jej žádali, aby tak učinil (Phillips 2020). Po údajném negativním výsledku Bolsonarova testu (z členů jeho vlády a skupiny, která s ním cestovala prezidentským letadlem navštívit prezidenta Trumpa v březnu, jich bylo dvacet tři testováno pozitivně), se Bolsonaro rozhodl setkat se se svými zastánci mimo prezidentský palác, a to bez roušky, s potřásáním rukama a společným focením, za což byl kritizován kvůli zbytečnému vystavování veřejnosti riziku nákazy. Ve stejné době Donald Trump, jehož Bolsonaro považuje za svůj vzor, veřejně trval na účinnosti léku hydroxychlorinu při léčbě COVID-19, ačkoli je toto tvrzení dosud neprokázané a jako takové je odsoudili přední brazilští epidemiologové a virologové a Světová zdravotnická organizace. Brazilští vědci, kteří studovali účinky hydroxychlorinu a dospěli k závěru, že není účinný a mohl by vést ke smrtelným vedlejším účinkům, čelili hrozbě smrti pravicovými aktivisty, což znovu ukázalo, jak se pandemie stala politickou otázkou (Kariny 2020).

Politický boj mezi Bolsonarem na jedné straně a na straně druhé Mandettou vedl vědce a guvernéry $\mathrm{k}$ pozoruhodné situaci. Federální Kongres, federální Senát a federální Nejvyšší soud nechtěli jakkoli podpořit Bolsonara $v$ jeho snaze vrátit se ke stavu před karanténou prostřednictvím prezidentského dekretu, jímž vyhrožoval. Dokonce chtěli aktivně zastavit jakýkoli pokus tento dekret prosadit a přijali rozhodnutí ve věcech, které obvykle spadají do prezidentových výsad (např. uzavření státních 
hranic). Vzhledem k tomu, že Brazílie má prezidentský režim, znamená to, že v tomto případě Bolsonaro neovládá zemi efektivně a byl prakticky obcházen místními vládami a ostatními federálními mocnostmi kvůli široce rozšířenému dojmu, že není schopen zvládnout situaci, což je názor sdílený dvěma třetinami populace podle posledních průzkumů veřejného mínění (Beedinelli 2020).

Bolsonarovy nesnáze předcházely koronavirovou krizi. Zdá se, že zklamal i mnoho těch, jež jej podporovali a doufali v radikální hospodářskou reformu privatizací veřejné správy, uvolněním pracovních zákonů, zvýhodněním soukromého sektoru a omezením už tak ubohého státního aparátu. Brazilská ekonomika navíc prochází těžkým obdobím; hospodářský růst v roce 2019 se zpomalil na 1,1 \% a národní měna, ta skutečná, nepřetržitě ztrácela cenu oproti americkému dolaru (který v březnu 2020 překročil symbolický práh pěti brazilských realů ${ }^{1}$, zatímco zahraniční investoři masově opouštějí brazilský finanční trh. 24. dubna se vzdal své funkce ministr spravedlnosti Sergio Moro (bývalý soudce, který odsoudil bývalého prezidenta Lulu k odnětí svobody a který je mezi konzervativními a pravicovými voliči extrémně populární), protože Bolsonaro, navzdory Morově radě, propustil velitele federální policie. Na tiskové konferenci, která byla vysílána živě a byla sledována širokou veřejností, Moro obvinil Bolsonara ze snahy zasahovat do činnosti Federální policie - pravděpodobně za účelem ochrany svých synů, kteří jsou vyšetřováni za šíření falešných zpráv proti politikům a soudcům Nejvyššího soudu prostřednictvím sociálních médií. Morova rezignace byla těžkou ranou pro Bolsonarovu popularitu. Výsledkem bylo, že se od Bolsonara odvrátilo mnoho původních spojenců, kteří však zatím nejsou ochotni ho obvinit, př́ípadně podpořit vojenský převrat, což je neustále zmiňovaná možnost, která nemůže být v jihoamerickém kontextu přehlížena. Důležité je v této záležitosti také to, že v př́ípadě obžaloby by byl Bolsonarovým nástupcem místoprezident Hamilton Mourão, armádní generál v důchodu. Bolsonarova prohlášení během současné krize je třeba číst ve světle tohoto boje o politické přežití a vidět značnou krizi v jeho vlastním kabinetu a mezi prezidentem a ostatními orgány, zejména parlamentem, Nejvyšším soudem a armádou.

To vedlo Bolsonara k ještě větší polarizaci jeho politického diskurzu, zřejmě za účelem mobilizace jeho volebního elektorátu. Zásadní postavení, které zaujal při odmítání rad lékařských expertů a rozhodnutí guvernérů jednotlivých brazilských států, jeho příznivci ocenili - zejména fundamentalističtí křestanští vůdci jako Silas Malafaia, hlava mocného kostela

1 V současné době je kurz jednoho USD 5,50 brazilských realů, což z realu činí skutečnou měnu s nejhorším „,ýkonem“ vůči americkému dolaru v roce 2020 (devalvace $28 \%)$. 
Shromáždění Boží (Assembléia de Deus), který se pokusil udržovat otevřené kostely navzdory karanténě (Pires 2020), a Edir Macedo, vedoucí Univerzální církve Božího království, který se vysmíval hysterii obyvatelstva a prohlašoval, že je to Satan, kdo šíŕi veškerý strach (Bergamo 2020).

Jeden z Bolsonarův synů, Eduardo (člen federálního Kongresu), opakovaně útočil na Čínu obviňováním z rozšíření viru (Phillips, T. 2020). Kontroverzní ministr školství Abraham Weintraub zase použil Twitteru k útoku na Čínu rasistickými příspěvky a konspiračními teoriemi (Čína prý virus úmyslně rozšířila, aby ovládla svět) (Phillips, T. 2020). Přes protesty čínské vlády nebyly vydány žádné omluvy; naopak, ministr zahraničních věcí kritizoval čínskou reakci. Zastánci Bolsonara, jehož volební kampaň byla vedena především prostřednictvím sociálních médií, masivně využili Facebooku, Twitteru a WhatsAppu k hájení jeho postoje ke karanténě a také jeho tvrzení o účinnosti hydroxychlorinu. Zároveň obviňují Mandettu a média z manipulace s údaji s cílem vytvořit paniku a úmyslně poškodit ekonomiku jako prostředek k ospravedlnění možné žaloby proti prezidentovi. Twitter, Facebook a Instagram zasáhly za účelem vymazání některých příspěvků samého Bolsonara, protože obsahovaly nepravdivé informace o viru, který by mohl ohrozit veřejné zdraví. ${ }^{2}$

\section{Ekonomická opatření}

V mezičase byla některá důležitá ekonomická opatření přijata také v Brazílii. Kongres schválil návrh na dodatek k ústavě, který by umožnil vytvoření paralelního „válečného rozpočtu“ výhradně v boji proti koronaviru. Pokud by byl schválen i Senátem, novela by nabyla platnosti, aniž by byl nutný souhlas prezidenta. Vláda se rozhodla dát šest set brazilských realů každému, kdo pracuje neoficiálně (nebot' neoficiální pracovní vztahy jsou v Brazílii stále běžnější než oficiální vztahy). Sociální program Bolsa Família, který za vlády Temera a Bolsonara utrpěl velké škrty, bude opět rozširren tak, aby se týkal většího počtu chudých rodin. Také vlivný ministr hospodářství Paulo Guedes (známý z minulosti svými neoliberálními postoji) naznačoval, že by mohl upustit od svých plánů zásadních ekonomických reforem, a dokonce zmínil možnost zvýšení veřejných výdajů na 147 miliard realů jako prostředku k oživení brazilské ekonomiky a boji proti pandemii (Rodrigues 2020).

2 Je pozoruhodné, že podobný postoj k pandemii koronaviru zaujal v Mexiku levicový prezident Andrés Manuel López Obrador, který se ještě v březnu pokusil minimalizovat význam epidemie, a vyzval Mexičany k vycházení, návštěvám restaurací a pokračování v normálním životě. V poslední době však uznává dopad krize a slíbil, že přijme „neortodoxni“" ekonomické opatření na pomoc lidem. 
Generál Walter Souza Braga Netto oznámil ještě větší plán masivních veřejných investic, který by v podstatě obnovil PAC (Plano de Aceleração Econômica - Program zrychlení ekonomiky), soubor politik přijatých bývalými levicovými vládami za účelem zlepšit ekonomiku. Současný plán však bude mít vlastenečtější jméno: Plano Pró-Brasil. Je zřejmé, že tento plán byl zjevně oznámen, aniž by se Braga Netto poradil s Guedesem, který by však mohl být př́štím ministrem, jenž opustí Bolsonarův kabinet. Převládající neoliberální kurz byl tedy prozatím odložen. Zároveň stojí za zmínku, že tyto oznámené investice nejsou přesně státní investice: vláda bude spíše podporovat tzv. partnerství soukromého a veřejného sektoru, takže peníze budou většinou plynout firmám, nikoli nejchudším lidem, kteří je potřebují více. To by mohlo vyústit v nějakou formu „socialismu pro bohaté", v níž stát, který následuje Matthewův princip, dává těm, kteří již mají, a zanedbává ty, kteří nemají nic. Takový důsledek by byl v souladu s tím, co se stalo ve většině brazilských dějin, počínaje koloniálními dobami, kdy portugalský král přiznal bohatým jednotlivcům výsadu vlastnit a využívat obrovské množství půdy s prakticky nulovou státní kontrolou. Následně to pokračovalo za císařství a republiky. Federální vláda dá nyní zahraničním korporacím obrovské částky na vybudování infrastruktury, aniž by kontrolovala jejich činnost, což patrně povede k tomu, že náklady exponenciálně porostou $\mathrm{v}$ důsledku korporátní chamtivosti a nehospodárnosti systému špatně navržených železnic a silnic (Bresser-Pereira 2014; Schwarcz - Starling 2017).

Brazílie poměrně brzy přijala ideologii desenvolvimentismo neboli developmentalismus (Furtado 1977; Furtado 2000), podle níž by hlavním zájmem vlády mělo být rozvíjení domácí ekonomiky, která přesahuje pouhý vývoz komodit. Tento cíl však nikdy nesledovala s nezbytnou důsledností, snad jen po určitou relativně krátkou dobu v autoritářském režimu Getúlia Vargase (1930 - 1945, 1951 - 1954), jenž vytvořil velké státní společnosti, které však byly časem většinou privatizovány. V současné době jsou nejdůležitějšími veřejnými společnostmi dvě hlavní národní banky, Banco do Brasil a Caixa Federal, a energetický kolos Petrobras, které se zatím vládě nepodařilo zprivatizovat. Jinými slovy, v současné době by brazilský stát nebyl schopen zahájit keynesiánskou politiku čistě veřejných investic, i když by samozrejmě mohl najmout veřejné zaměstnance, což je však něco, co je za současné vlády nepravděpodobně kvůli všeobecné nedůvěře vůči státu mezi voliči.3 Za účelem budování infrastruktury nebo

3 Tuto nedůvěru lze částečně ospravedlnit historickou absencí státu v mnoha regionech země, které byly ponechány napospas sobě samým a ve kterých mají místní vlastníci půdy nebo lídři větší pravomoc než vláda. Odpovídá to ale také agresivní protivládní rétorice, která se v poslední době stala stále dominantnější a byla pod- 
výroby zboží by se stát musel spoléhat na soukromé společnosti, které by ale pravděpodobně znamenaly rostoucí náklady a špatné výsledky, jako tomu bylo v minulosti skoro pokaždé.

Provedeme-li krátké srovnání Brazílie s Argentinou, vyznívá Argentina jako protipól. Infekce se v Argentině začala šírit začátkem března. První úmrtí bylo hlášeno 7 . března a následně 19. března vláda zavedla celonárodní karanténu. K datu 5. 5. 2020 je počet potvrzených př́padů 5020 , počet úmrtí 264. Oproti Brazílii postupovala Argentina na národní úrovni velmi rychle, přičemž federální vláda vyzvala k úplné karanténě, která je př́sně dodržována pod hrozbou vysokých pokut, a dokonce uvězněním pro ty, kteří tato pravidla nedodržují. Výsledkem je, že počet infikovaných lidí a úmrtí je výrazně nižší než v Brazílii. Fernándezova vláda reagovala od začátku dodržováním doporučení vědců a Světové zdravotnické organizace a pomáhá zejména těm, kteří patří k rizikovým skupinám: tj. starším a již chronicky nemocným lidem ad. Opatření zahrnují přímé platby peněz zranitelným rodinám, osvobození určitých kategorií od placení konkrétních druhů dluhů, zpřístupnění potravin a léků starým a nemocným lidem. Vláda se také rozhodla zvýšit veřejné výdaje, aby pomohla ekonomiku znovu nastartovat. Vzhledem k tomu, že země prochází závažnou hospodářskou krizí a vláda se pokoušela znovu projednat svůj dluh, není jasné, prostřednictvím jakých finančních zdrojů budou tato opatření realizována. Dne 5. dubna Argentina oznámila, že odloží splácení svého dluhu do roku 2021, tedy učinila opatření, které brazilská vláda zřejmě rozhodně nemá $v$ úmyslu přijmout.

\section{Občanské reakce}

Zdá se, že občané reagovali na karanténu se smíšenými pocity. Zatímco podle některých průzkumů více než $75 \%$ lidí toto opatření vítá, existuje mnoho zpráv o jeho porušování. Zejména $v$ chudých periferiích a ve favelách mnoho lidí očividně vzdoruje karanténním opatřením bud' proto, že věři Bolsonarovým slovům o neohroženosti a církevním hodnostářům, nebo proto, že nemají jinou šanci na přežití než věnovat se své práci

\footnotetext{
porována pravicovými think-tanky financovanými brazilskými podnikateli a zahraničními, většinou americkými dárci. Libertariánské myšlenky („daně jsou krádež“) a etický egoismus inspirovaný objektivismem Ayn Randové se staly běžnými mezi vzdělanou střední třídou. Spolu s nejchudšími třídami novoletniční církve se stávaly čím dál vlivnějšími tím, že kázaly to, co se nazývá „teologie prosperity“, podle níž si Bůh přeje, abychom zbohatli, a nepožaduje, abychom přispívali na charitu (avšak trvá na desátcích). Tento nový vývoj přispívá $\mathrm{k}$ tradicionalismu a rasismu, který prostupuje brazilskou společností, čímž se zde vytrácí skutečný smysl pro národní solidaritu a př́slušnost k národnímu společenství.
} 
v šedé ekonomice. Lidé totiž čelí velkým byrokratickým překážkám, aby mohli získat slibovanou pomoc od federální vlády, tj. výše uvedených šest set brazilských realů. Ve velkoměstech je zdravotní systém pod tlakem a nemocnice již někdy nejsou schopny vyrovnat se s počtem infikovaných, kteří potřebují hospitalizaci. Např́íklad v Riu de Janeiru je dlouhý seznam čekajících na lůžko v intenzivní péči (Lucchese - Campos 2020; de Palhano 2020). Fotografie společných hrobů vykopávaných na hřbitovech v Manausu se dostaly do mezinárodního tisku. Jakmile se virus začne více šírit ve favelách, odborníci se obávají, že počet případů by se mohl rychle zvýšit kvůli nedostatku základních hygienických podmínek (mnoho obydlí nemá tekoucí vodu, což prakticky znemožňuje přijímat preventivní opatření, jakým je mytí rukou) a obtížnému dodržování sociálního odstupu ve vysoce obydlených oblastech. Útěcha přichází méně od veřejných orgánů a spíše od nevládních organizací, progresivních církví a místních sousedských skupin, což vede k obrodě ducha pospolitosti, který charakterizoval favely $\mathrm{v}$ minulosti a který v posledních letech slábl, v neposlední řadě kvưli individualistickému přístupu obhajovanému některými vlivnými novoletničními církvemi (Phillips 2020c).

Zatímco se epidemie šírí po celé Brazílii a kontinentu, vzrůstá obava z osudu domorodých obyvatel v Jižní Americe. Odborníci varují, že pokud se virus dostane $\mathrm{k}$ domorodým populacím zejména $\mathrm{v}$ jejich izolovaných vesnicích, dopad může být strašlivý, s extrémně vysokým počtem úmrtí (Collyns - Cowie - Daniels - Phillips 2020). Z tohoto důvodu se brazilští soudci pokoušejí zabránit křest’anským misionářům, kteří se po Bolsonarových volbách stali velmi aktivními, v navazování kontaktů s izolovanými kmeny žijícími v rezervacích (Phillips 2020b). Domorodé obyvatelstvo čelí skutečné genocidě - zejména za vlády, která v první řadě hájí zájmy korporací, aby využívala půdu původních rezervací hlavně pro pěstování skotu nebo pro těžbě nerostů. Vláda se přitom ani nesnaží zastavit masakry domorodých obyvatel, které provádějí ozbrojenci najatí korporacemi, a pokouší se podkopat práva domorodců, jak jen to je možné.

\section{Závěrečné reflexe}

Způsob, jakým krize současné pandemie ovlivňuje Brazílii a obecněji Jižní Ameriku, je pro sociálního filosofa potvrzením potřeby fungujícího a silného státního aparátu, když jde o ochranu obyvatelstva obecně, a zejména jeho nejzranitelnějších skupin, které v regionu představují většinu. Dopad krize bude mnohem horší než v Evropě, a to nejen $\mathrm{z}$ epidemiologického hlediska, ale také z hlediska sociálního a politického. Mnoho lidí zemře kvůli nedostatečnosti systému veřejného zdravotnictví (nedostatek lůžek 
v nemocnici, nedostatek osobních ochranných prostředků atd.) a nedostatku základních hygienických standardů (nedostatek tekoucí nezávadné vody, nedostatek kanalizací atd.), které jsou důsledkem lhostejnosti státu k životnímu stavu nejchudších občanů. Hlad a podvýživa se mezi chudými pravděpodobně znovu stanou běžnými zejména ve venkovských oblastech, kde není možné zlepšit ekonomickou situaci bez masivních státních zásahů, které se v současnosti zdají docela nepravděpodobné (Rego Pinzani 2018). Osud domorodých obyvatel však mưže být ještě horší. Finanční úsilí státu bude opět přínosem pro soukromé korporace a jejich movité majitele, přičemž chudé a střední třídy zůstanou stranou. To by mohlo vést $\mathrm{k}$ sociálním nepokojům jako $\mathrm{v}$ Chile nebo, pravděpodobněji, vzhledem k tomu, co se stalo během prezidentské kampaně v roce 2018, k rostoucí touze po „silných vůdcích“.

Je samozřejmě možné, že se stane neočekávané a že stále více lidí si začne uvědomovat dủležitost státu a vládních výdajů, jak se to děje v Evropě, avšak v současné době neexistuje důkaz, že by se věci mohly vydat touto cestou. Naopak, orgány veřejné správy jsou obviňovány bud’ z blokování chodu ekonomiky, nebo z toho, že se nevypořádaly s naléhavou lékařskou pomocí. Stát je tedy paradoxně obviňován z toho, že je příliš aktivní, nebo nedostatečně aktivní. Slabost státu se odráží v nedůvěře vůči státu, kterou sdílí mnoho občanů, i když z různých důvodů (Soares 2019; Streck et al. 2011).

Na závěr dodám, že pandemie zasáhla rovněž vztahy mezi jihoamerickými zeměmi. 25. dubna argentinská vláda ohlásila, že zanechá současná a budoucí jednání s ostatními zeměmi Mercosuru s cílem zaměřit se na oživení domácího hospodářství (Resende 2020). Stalo se to při prvním podezření z toho, že by krize pandemie mohla bránit už tak pomalému a nejistému procesu ekonomické integrace mezi členy Mercosuru. V současné době nelze uvažovat o spolupráci či mezinárodní vzájemné podpoře mezi jihoamerickými zeměmi. Každá z nich se snaží vypořádat se s virem a hospodářskou reakcí na karanténní opatření a její následky poměrně samostatně. Výše uvedené okolnosti a fakt, že žádná ze zemí nemá silný systém veřejných služeb a většina $\mathrm{z}$ nich $\mathrm{v}$ posledním období přijala neoliberální opatření, jejichž cílem je vytvoření slabé vlády a minimálního státu, zanechává jejich výkonné a zákonodárné pravomoci s př́liš malým množstvím zdrojů na to, aby mohly čelit k velkým výzvám, které pandemie představuje.

Článek z anglického do českého jazyka přeložila Marie Hlavičková 


\section{Literatura}

AVRITZER, L. (2019): O pêndulo da democracia. São Paulo: todavia.

BEDINELLI, T. (2020): Gestão de Bolsonaro do coronavírus é reprovada por 64\%, e 45\% se dizem a favor de impeachment. In: El País 19. 3. 2020. Web. 25. 4. 2020. <https://brasil.elpais.com/brasil/2020-03-19/gestao-de-bolsonaro-docoronavirus-e-reprovada-por-64-e-45-se-dizem-a-favor-de-impeachment. html>.

BERGAMO, M. (2020): Vídeo mostra Edir Macedo dizendo que coronavírus é inofensivo e que Satanás e mídia promovem medo. In: Folha de S. Paulo 15. 3. 2020. Web. 25. 4. 2020. <https://www1.folha.uol.com.br/colunas/ monicabergamo/2020/03/video-mostra-edir-macedo-dizendo-quecoronavirus-e-inofensivo-e-que-satanas-e-midia-promovem-medo.shtml>.

Bolsonaro diz que "pequena crise" do coronavírus é "mais fantasia" e não "isso tudo" que mídia propaga. In: Globo 10. 3. 2020. Web. 25. 4. 2020. <https:// g1.globo.com/politica/noticia/2020/03/10/bolsonaro-diz-que-questao-docoronavirus-e-muito-mais-fantasia.ghtml>.

Brazilian minister Guedes apologizes for calling state employees as "parasites". In: MercoPress 12. 4. 2020. Web. 25. 4. 2020 <https://en.mercopress.com/2020/02/12/brazilian-minister-guedes-apologizes-for-callingstate-employees-as-parasites>.

BRESSER-PEREIRA, L. C. (2014): A construção política do Brasil. Sociedade, economia e Estado desde a Independência. São Paulo: Editora 34.

CARDOSO, F. H. - FALETTO, E. (1970): Dependência e desenvolvimento na América Latina. Rio de Janeiro: LTC Editora.

Cartórios registram aumento de $1.035 \%$ nas mortes por síndrome respiratória. In: Jornal Nacional 28. 4. 2020. Web. 25. 4. 2020 <https://g1.globo.com/jornalnacional/noticia/2020/04/28/cartorios-registram-aumento-de1035percent-nas-mortes-por-sindrome-respiratoria.ghtml>.

COLLYNS, D. - COWIE, S. - DANIELS, J. P. - PHILLIPS, T. (2020): “Coronavirus could wipe us out": indigenous South Americans blockade villages. In: The Guardian 30. 3. 2020. Web. 25. 4. 2020. <https://www.theguardian.com/world/2020/ mar/30/south-america-indigenous-groups-coronavirus-brazil-colombia>.

DE PALHANO, G. (2020): Pelo menos 145 pacientes com falta de ar em emergências no Rio morreram em abril à espera de internação. In: Globo 25. 4. 2020. Web. 25. 4. 2020. <https://g1.globo.com/rj/rio-de-janeiro/noticia/2020/04/25/ pelo-menos-145-pacientes-de-emergencias-com-falta-de-ar-no-riomorreram-em-abril-a-espera-de-internacao.ghtml>.

FERNANDES, F. (1981): Poder e contrapoder na América Latina. Rio de Janeiro: Jorge Zahar.

FURTADO, C. (1977): Economic Development of Latin America. Historical Backgrounds and Contemporary Problems. Cambridge: Cambridge University Press.

FURTADO, C. (2000): Teoria e política do desenvolvimento econômico. Rio de Janeiro: Paz e Terra. 
KARINY, I. (2020): Fiocruz se manifesta em defesa de pesquisadores que sofreram ataques por estudos da cloroquina, i. In: OPOVO online 17. 4. 2020. Web. 25. 4. 2020. <https://www.opovo.com.br/coronavirus/2020/04/17/ fiocruz-se-manifesta-em-defesa-de-pesquisadores-que-sofreramataques-por-estudos-da-cloroquina.html>.

LUCCHESE, B. - CAMPOS, Ch. (2020): Fila de espera por leitos com respiradores no Rio já tem 230 pessoas. In: Globo 24. 4. 2020. Web. 25. 4. 2020. <https://g1. globo.com/rj/rio-de-janeiro/noticia/2020/04/24/fila-de-espera-por-leitoscom-respiradores-no-rio-ja-tem-230-pessoas.ghtml>.

Notificações de mortes por causa indeterminada disparam em cartórios do Rio, In: Jornal Nacional 28. 4. 2020. <https://g1.globo.com/jornal-nacional/ noticia/2020/04/28/notificacoes-de-mortes-por-causa-indeterminadadisparam-em-cartorios-do-rio.ghtml>.

Os governos municipais frente ao Coronavírus, in: Núcleo de Estudos sobre Política Local (NEPOL). 24. 4. 2020. Web. 25. 4. 2020. <https://nepolufjf.wordpress. com/os-governos-municipais-frente-ao-coronavirus/>.

PHILLIPS, D. (2020a): Brazil congress demands Jair Bolsonaro release results of his COVID-19 tests. In: The Guardian 15. 4. 2020. Web. 25. 4. 2020. <https://www. theguardian.com/world/2020/apr/15/jair-bolsonaro-brazil-coronavirustests-results>.

PHILLIPS, D. (2020b): Brazil: judge bans missionaries from indigenous reserve over COVID-19 fears. In: The Guardian 17. 4. 2020. Web. 25. 4. 2020. <https://www.theguardian.com/world/2020/apr/17/brazil-judge-bansmissionaries-coronavirus-amazon-indigenous-reserve $>$.

PHILLIPS, D. (2020c): "We're abandoned to our own fate": coronavirus menaces Brazil's favelas. In: The Guardian 14. 4. 2020. Web. 25. 4. 2020. <https://www.theguardian.com/global-development/2020/apr/14/ were-abandoned-to-our-own-luck-coronavirus-menaces-brazils-favelas $>$.

PHILLIPS, T. (2020): Bolsonaro's son enrages Beijing by blaming China for coronavirus crisis. In: The Guardian 19. 3. 2020. Web. 25. 4. 2020. <https://www. theguardian.com/world/2020/mar/19/coronavirus-bolsonaro-son-chinarow>.

PIRES, B.(2020): Igrejas desafiamrecomendaçãodesuspendermissasecultos diante da pandemia do coronavírus. In: El País 20. 3. 2020. Web. 25. 4. 2020. <https:// brasil.elpais.com/brasil/2020-03-20/igrejas-desafiam-recomendacaode-suspender-missas-e-cultos-diante-da-pandemia-do-coronavirus.html $>$.

POWER, T. J. - JAMISON, G. D. (2005): Political mistrust in Latin America. In: Comparative Sociology, $4(1-2), 47-72$.

REGO, W. L. - PINZANI, A. (2018): Money, Autonomy, and Citizenship. The Experience of the Brazilian Bolsa Família. Cham: Springer.

RESENDE, M. (2020): Coronavírus: Argentina abandona negociações do Mercosul para priorizar política econômica interna. In: Globo 25. 4.2020. Web. 25.4. 2020. <https://g1.globo.com/economia/noticia/2020/04/25/coronavirusargentina-abandona-negociacoes-do-mercosul-para-priorizar-politicaeconomica-interna.ghtml>. 
RODRIGUES, D. (2020): Guedes anuncia pacote de R $\$ 147$ bilhões para combater pandemia de COVID-19. In: Poder 360 16. 3. 2020. Web. 25. 4. 2020. <https:// www.poder360.com.br/economia/guedes-anuncia-pacote-de-r-147-bilhoespara-combater-pandemia-de-covid-19/>.

SCHWARCZ, L. M. - STARLING, H. M. (2017): Brasil: Uma biografia. São Paulo: Companhia das Letras.

SOARES, L. E. (2019): O Brasil e seu duplo. São Paulo: todavia.

STRECK, D. R. - EGGERT, E. - SOBOTTKA, E. - ADAMS, T. - ZANINI MORETTI, C. (2011): Research, participation and social transformation: notes on the unfolding of a research practice. In: International Journal of Action Research, 7 (2), $175-195$.

WORLD ECONOMIC OUTLOOK DATABASE, October 2019 (cit. 25. 4. 2020).

\section{Prof. Alessandro Pinzani, PhD.}

Universidade Federal de Santa Catarina

Santa Catarina

Brazil

alepinzani@gmail.com

Centrum globálních studií

Filosofický ústav Akademie věd ČR

Jilská 1, 11000 Praha 1

Česká republika 